\title{
Sarcopenia and Muscle Aging: A Brief Overview
}

\author{
Tam Dao ${ }^{1, *}$, Alexander E. Green ${ }^{2,3}$, Yun A Kim ${ }^{1}$, Sung-Jin Bae ${ }^{4}$, Ki-Tae Ha ${ }^{4,5}$, Karim Gariani ${ }^{6,7}$, \\ Mi-ra Lee ${ }^{8}$, Keir J. Menzies ${ }^{2,3,9}$, Dongryeol Ryu ${ }^{1,10,11}$
}

${ }^{1}$ Department of Molecular Cell Biology, Sungkyunkwan University School of Medicine, Suwon, Korea; ${ }^{2}$ University of Ottawa Eric Poulin Centre for Neuromuscular Disease; ${ }^{3}$ Interdisciplinary School of Health Sciences, Faculty of Health Sciences University of Ottawa, Ottawa, ON, Canada; ${ }^{4}$ Korean Medical Research Center for Healthy Aging, Pusan National University; ${ }^{5}$ Department of Korean Medical Science, Pusan National University School of Korean Medicine, Yangsan, Korea; ${ }^{6}$ Service of Endocrinology, Diabetes, Nutrition and Therapeutic Patient Education, Geneva University Hospitals; ${ }^{7}$ Faculty of Medicine, University of Geneva, Geneva, Switzerland; ${ }^{8}$ Department of Social Welfare, Division of Public Service, Dong-Eui University, Busan, Korea; ${ }^{9}$ Department of Biochemistry, Microbiology and Immunology, Faculty of Medicine, University of Ottawa, Ottawa, ON, Canada; ${ }^{10}$ Biomedical Institute for Convergence at SKKU (BICS), Sungkyunkwan University, Suwon; ${ }^{11}$ Samsung Biomedical Research Institute, Samsung Medical Center, Seoul, Korea

The world is facing the new challenges of an aging population, and understanding the process of aging has therefore become one of the most important global concerns. Sarcopenia is a condition which is defined by the gradual loss of skeletal muscle mass and function with age. In research and clinical practice, sarcopenia is recognized as a component of geriatric disease and is a current target for drug development. In this review we define this condition and provide an overview of current therapeutic approaches. We further highlight recent findings that describe key pathophysiological phenotypes of this condition, including alterations in muscle fiber types, mitochondrial function, nicotinamide adenine dinucleotide $\left(\mathrm{NAD}^{+}\right)$metabolism, myokines, and gut microbiota, in aged muscle compared to young muscle or healthy aged muscle. The last part of this review examines new therapeutic avenues for promising treatment targets. There is still no accepted therapy for sarcopenia in humans. Here we provide a brief review of the current state of research derived from various mouse models or human samples that provide novel routes for the development of effective therapeutics to maintain muscle health during aging.

Keywords: Skeletal muscle; Sarcopenia; Aging; Mitochondria; NAD+; Urolithin; Mitophagy; Gastrointestinal microbiome; Exercise

Received: 4 November 2020, Revised: 26 November 2020 ,

Accepted: 30 November 2020

Corresponding authors: Dongryeol Ryu

Department of Molecular Cell Biology, Sungkyunkwan University School of Medicine, 2066 Seobu-ro, Jangan-gu, Suwon 16419, Korea

Tel: +82-31-299-6138, E-mail: freefall@skku.edu

Keir J. Menzies

Eric Poulin Centre for Neuromuscular Disease, Interdisciplinary School of Health

Sciences, University of Ottawa, Ottawa, ON K1N 6N5, Canada

Tel: +1-613-562-5800, E-mail: kmenzies@uottawa.ca

Mi-ra Lee

Department of Public Service, Dong-Eui University, 176 Eomgwang-ro, Busanjingu, Busan 47340, Korea

Tel: +82-51-890-2038, E-mail: miracle9025@deu.ac.kr

*These authors contributed equally to this work.

\section{Copyright $(92020$ Korean Endocrine Society}

This is an Open Access article distributed under the terms of the Creative Commons Attribution Non-Commercial License (https://creativecommons.org/ licenses/by-nc/4.0/) which permits unrestricted non-commercial use, distribution, and reproduction in any medium, provided the original work is properly cited. 


\section{INTRODUCTION}

Worldwide advances in applied science and health care technology, along with socioeconomic development, has increased lifespan. In 2019, it was estimated that globally 703 million people were older than 65 years old and that this number would reach 1.5 billion by 2050 [1]. All nations have seen an increase in life expectancy with a disproportionately greater increase in elderly populations [1]. Consequently, healthcare services are strained under the additional burden of increasing elderly populations. A better understanding of age-related chronic diseases and new modalities are required to address aging-related diseases and alleviate pressure on healthcare systems.

One such disease is sarcopenia. Sarcopenia is the progressive and generalized loss of muscle mass and function (i.e., strength) that occurs with age [2] and is strongly associated with frailty. Frailty is defined by the vulnerability of the elderly to possible stressors that increase risk for poor health outcomes, incident disability, and mortality [3]. Recent studies have revealed that sarcopenia is not a simple condition caused by nutrient deficiency or a sedentary lifestyle, but a result of an elaborate multipathway pathogenesis $[4,5]$. This article presents a brief overview of the current knowledge of the underlying mechanisms of sarcopenia along with novel therapies being explored to prevent and treat this condition.

\section{SARCOPENIA}

\section{Sarcopenia}

The Aging in Motion (AIM) Coalition describes sarcopenia as a type of persistent muscle atrophy characterized by gradual loss of skeletal muscle mass and function (strength) with a risk of negative outcomes such as physical disability, poor quality of life and death. Additionally, in 2016, sarcopenia became officially classified as a disease state under the International Classification of Diseases, Clinical Modification (ICD-10-CM) code (M62.84) [6], thus emphasizing the need for improved diagnostic methods and drug development to treat sarcopenia. For instance, in 1998 using dual X-ray absorptiometry, Baumgartner et al. [7] proposed sarcopenia as any appendicular skeletal muscle mass $(\mathrm{kg}) /$ height $\left(\mathrm{m}^{2}\right)$ that was $>2$ standard deviations (SDs) beneath that of a young reference population's mean. Similarly, in 2003, using computed tomography scans of calf muscle, Lauretani et al. [8] defined sarcopenia as a muscle cross-sectional area that was $>2$ SDs below the population mean. In 2010, the European Working Group on Sarcopenia in Older People (EWGSOP) suggested that sarcopenia should be clinically defined by both reduced muscle quantity and degraded muscle quality (i.e., strength or performance) [9]. Eight years later, based on more laboratory and clinical evidence, EWGSOP updated their consensus. They determined that low muscle strength was the primary defining attribute of sarcopenia, and that low muscle mass and quality are confirmatory markers of sarcopenia diagnosis, with severe sarcopenia defined by additional impaired physical performance [10].

Currently, many regional and international organizations, such as the EWGSOP, the Asian Working Group for Sarcopenia (AWGS), the International Working Group on Sarcopenia (IWGS), and the Foundation for the National Institutes of Health (FNIH), have proposed various diagnostic criteria and screening stratgeis for sarcopenia, which are summarized in Table 1 [10-13]. In general, these groups agree on diagnosing sarcopenia using both mus-

Table 1. Summary of Recommendations in the Diagnostic Criteria for Sarcopenia

\begin{tabular}{|c|c|c|}
\hline Organization & Highlight & Reference \\
\hline $\begin{array}{l}\text { European Working Group on } \\
\text { Sarcopenia in Older People } \\
\text { (EWGSOP) }\end{array}$ & $\begin{array}{l}\text { EWGSOP2 utilizes low muscle quality as the primary criterion of sarcopenia; muscle quality is directly } \\
\text { the most solid proportion of muscle function. The diagnosis is made based on appendicular skeletal } \\
\text { muscle mass calculated from dual-energy X-ray absorptiometry scan, skeletal muscle index, handgrip } \\
\text { strength, and gait speed. }\end{array}$ & [10] \\
\hline $\begin{array}{l}\text { Asian Working Group for } \\
\text { Sarcopenia (AWGS) }\end{array}$ & $\begin{array}{l}\text { Estimating both muscle quality (handgrip quality) and physical execution (common walk speed) as the } \\
\text { screening test, specifying cutoff points of a similar index with EWGSOP2 based on Asian population } \\
\text { characteristics. }\end{array}$ & [11] \\
\hline $\begin{array}{l}\text { International Working Group on } \\
\text { Sarcopenia (IWGS) }\end{array}$ & $\begin{array}{l}\text { Emphasizes consideration of sarcopenia in bedridden and low gait speed patients, and uses a combination } \\
\text { of gait speed and a measurement of low muscle mass to give the sarcopenia diagnosis. }\end{array}$ & {$[12]$} \\
\hline $\begin{array}{l}\text { Foundation for the National } \\
\text { Institutes of Health (FNIH) }\end{array}$ & $\begin{array}{l}\text { Focuses on how physicians make differential diagnosis among older people with physical restrictions. } \\
\text { Their recommendation contains cutoffs for both sexes, using similar indexes to EWGSOP2 and AWGS, } \\
\text { but considers them in relationship with body mass index. }\end{array}$ & [13] \\
\hline
\end{tabular}


cle mass and muscle function together; however, they use different measurement tools and thresholds. Despite these differences, sarcopenia is generally diagnosed in about $20 \%$ of elderly research subjects with similar proportions for Caucasian and Asian populations $[14,15]$. Additionally, sarcopenia is exceptionally common in people with cardiovascular disease, dementia, diabetes mellitus, and respiratory disorders [16].

\section{AGING OF SKELETAL MUSCLE}

\section{Anabolic resistance}

Normally, muscle contraction, dietary amino acids, and anabolic hormones, such as insulin like growth factor-1 (IGF-1), are potent stimulators of muscle growth. However, when muscle becomes resistant to these stimuli this is termed anabolic resistance (AR). AR is a phenomenon defined by the diminished ability to increase the rate of protein synthesis and adapt to anabolic stimulation $[17,18]$. AR is often observed in aged muscle and is probably a crucial driver of sarcopenia and physical frailty $[19,20]$. It may underlie the greater requirement for dietary protein in older adults [21]. Although the underlying mechanisms remain to be fully elucidated, it is primarily thought to be due to reduced sensitivity of AKT (also known as protein kinase $\mathrm{B}$ [PKB])-mammalian target of rapamycin (mTOR) kinase cascade $[17,19,21,22]$. AR is likely one of many contributing factors to sarcopenia.

\section{Muscle fiber-type}

Muscle consists of force-generating contractile muscle fibers bundled together by connective tissue. The sarcomere is the functional unit of muscle fiber, containing thin filaments (including actin, tropomyosin, and troponin) and thick filaments (primarily comprised of myosin), along with other structural proteins. ATP-dependent crawling of myosin filaments along actin chains generates muscle contraction. Mature myosin protein contains six polypeptides, four light chains, and two heavy chains [23]. The expression of different myosin heavy chain (MHC) isoforms determines muscle fiber types. Classically, adult human skeletal myofibers have been classified as either slow-twitch (type I) or fast-twitch (type II) fiber types, according to their contractile speed in response to neural excitement. Presently, myofibers are classified as type I, type IIA, IIB, or IIX, in parallel with the MHC isoform expressed. Type I and IIA fibers predominantly depend on mitochondrial oxidative phosphorylation for energy production, whereas type IIB and IIX rely on glycolysis [23].
Several reports show that aging causes muscle fiber-type transition that is characterized by a gradual decrease of both type II fiber number and size with age [24,25] suggesting a fast to slow fiber-type shift. This is further supported by a study that found that expression of IIA and IIX MHC mRNA decreased by $14 \%$ and $10 \%$, respectively, per decade while type I mRNA remained constant with age [26]. Additionally, by analyzing single myofiber expression of MHC proteins, Klitgaard et al. [27] found that with age there is an increase in fibers co-expressing multiple MHC isoforms. Increased clustering of myofibers of similar types has been shown to be associated with both samples from patients with spinal muscular atrophy and in subjects over the age of 50 [28]. This muscle fiber-type shift from fast to slow may also suggest that with aging skeletal muscle transitions from relying primarily on cytosolic glycolytic metabolism to oxidative metabolism and thus has a greater requirement for functional mitochondria.

\section{Mitochondrial dysfunction}

Although, classically, mitochondria are considered the cellular power plants of eukaryotic cells, recent evidence describes mitochondria as multifunctional signaling hubs, linking various cellular functions to metabolic and age-associated diseases [29]. Mitochondria play pivotal roles in cellular homeostasis responding to intracellular and extracellular stresses, cell death, inflammation, epigenetics, and senescence [30]. Mitochondrial dysfunction describes the functional decline of mitochondrial quality and activity due to destruction of mitochondrial structure, reduction of mitochondrial content, malfunction of mitochondrial metabolism and oxidative phosphorylation, accumulation of mitochondrial DNA damage, and dysregulation of mitochondrial dynamics (fusion and fission) [31] and is a well-recognized "hallmark of aging" [29,32].

Many reports have demonstrated that sarcopenia is tightly associated with mitochondrial dysfunction in skeletal muscles as well as motor neurons [33,34]. For instance, recently, using muscle biopsies from 119 human elderly subjects drawn from Caucasian, African, and Asian cohorts, Migliavacca et al. [35] found reduced mitochondrial oxidative capacity and nicotinamide adenine dinucleotide $\left(\mathrm{NAD}^{+}\right)$biosynthesis in sarcopenic individuals. Furthermore, several studies have proposed that mitochondrial dysfunction in motor neurons drives sarcopenia [36,37]. In addition, studies using muscle transcriptomes revealed reduced expression of many mitochondrial genes, including peroxisome proliferator-activated receptor- $\gamma$ coactivator $1-\alpha$ (PGC-1 $\alpha)$ and estrogen related receptors (ERRs), both key 
regulatory factors of mitochondrial biogenesis and homeostasis [38]. In our unpublished work analyzing publicly available Genotype-Tissue Expression (GTEx) data and National Center for Biotechnology Information (NCBI) Gene Expression Omnibus (GEO) data, the expression of the majority of both nuclear and mitochondrial DNA-encoded mitochondrial genes is reduced in muscle from aged rodents and humans.

Interestingly, mitophagy, which selectively eliminates damaged or dysfunctional mitochondria via autophagy, is also reduced during normal aging [39]. The requirement of autophagy for muscle maintenance was demonstrated with the observation that mice lacking $\operatorname{Atg} 7$ in muscle, a key enzyme required for muscle autophagy, experience premature muscle dysfunction and sarcopenia [40]. Similarly, overexpression of Atg5 in mice increases autophagic protein expression and prevents age-induced decreases in muscle function [41]. This finding suggests that autophagy may be required to maintain muscle function with age. Several recent studies demonstrated that the enhancement of mitophagy by the administration of single compounds, such as urolithins [42-44] and spermidine [45], led to beneficial effects in aged skeletal muscle, heart, and neurons. These data suggest that mitophagy enhancers could provide new therapeutic options to treat sarcopenia. In summary, mitochondrial dysfunction is associated with sarcopenia with many contributing factors. These include but are not limited to reduced PGC-1 $\alpha$ and ERR signaling, insufficient autophagy/mitophagy, and reduced muscular $\mathrm{NAD}^{+}$levels with age.

\section{$\mathrm{NAD}^{+}$metabolism}

$\mathrm{NAD}^{+}$is a well-known essential biomolecule. It is a substrate for many enzymes, including poly(ADP-ribose) polymerase 1 (PARP1) and sirtuin 1 (SIRT1), and essential for metabolic processes where it accepts and donates electrons for glycolysis, $\beta$-oxidation, the tricarboxylic acid cycle, and the electron transport chain [46]. Numerous independent studies have found that cellular $\mathrm{NAD}^{+}$levels decline in the majority of tissues, including skeletal muscle, liver, adipose tissue, and adult stem cells, with aging and pathological conditions [47-49]. This suggests that $\mathrm{NAD}^{+}$is associated with aging and presumably diseases such as sarcopenia. As aforementioned, $\mathrm{NAD}^{+}$biosynthesis is reduced in skeletal muscle from Caucasian, African, and Asian sarcopenic cohorts [35]. In support of a causative role of $\mathrm{NAD}^{+}$ deficiency in muscular atrophy, mice with impaired $\mathrm{NAD}^{+}$salvage pathways in muscle, i.e., skeletal muscle-specific NAMPT knockout (KO) mice, Frederick et al. [49] observed increased mitochondrial dysfunction, decreased muscle mass and func- tion, that was exacerbated with age. Subsequently, researchers investigated the therapeutic potential of $\mathrm{NAD}^{+}$boosting molecules [50]. $\mathrm{NAD}^{+}$replenishment using $\mathrm{NAD}^{+}$boosters, including nicotinamide riboside (NR), nicotinamide mononucleotide (NMN), nicotinamide (NAM), CD38 inhibitors and PARP inhibitors, protects from age- or congenital disease-related muscle phenotypes [51-55]. NR supplementation alone improves muscle satellite cell regenerative capacity and rescues the muscular atrophy phenotype of mice lacking skeletal muscle NAMPT [49]. Similarly, overexpression of a constitutively active NAMPT maintains muscle $\mathrm{NAD}^{+}$levels and exercise performance in old mice, demonstrating the essential role of tissue-autonomous $\mathrm{NAD}^{+}$homeostasis $[55,56]$.

\section{MYOKINES AND MUSCLE AGING}

\section{Myostatin and follistatin}

Myostatin (encoded by the MSTN gene, also known as growth differentiation factor 8 [GDF-8]) is a myokine that negatively regulates myogenesis [57]. It belongs to the transforming growth factor- $\beta$ (TGF $\beta$ ) family, is secreted from muscle, and has local (autocrine) or systemic (endocrine) effects by acting on activin type II A and B (ActRIIA/B) receptors. Animal models lacking myostatin and humans with congenital myostatin loss experience pronounced muscle loss and indicated the negative relationship between myostatin expression and muscle size [58-60]. In contrast, follistatin, also a member of the TGF $\beta$ family, is a competitive antagonist for myostatin binding to the ActRIIB receptor $[57,58]$. Follistatin was first found in ovarian follicular fluid and later in skeletal muscle, testis, liver and many different tissues $[57,58]$. Reciprocal to ablation of myostatin, overexpression or administration of recombinant follistatin causes muscle hypertrophy $[57,58,61]$. Thus, myostatin and follistatin are both known regulators of muscle mass.

However, the role of myostatin and follistatin in sarcopenia is unclear. In $\mathrm{C} 2 \mathrm{C} 12$ myoblasts, myostatin was elevated in late passage ( $>30$ passages) versus early passage ( $<12$ passages) [62]. These findings have been confirmed by some studies in older humans and animal subjects where with increasing age and sarcopenia there is also increased expression of myostatin $[63,64]$. However, not all studies come to the same conclusion. Bergen et al. [63] observed this to be true only in female but not male participants, supporting the increased incidence of sarcopenia in females. Furthermore, Ratkevicius et al. [65] observed no differences in serum myostatin between young and sarcopenic elderly men. Similarly, follistatin does not appear to change with age 
$[63,66]$. These conflicting findings suggest that despite their clear potential for regulation of muscle mass myostatin and follistatin may not directly contribute to sarcopenia or muscle aging.

\section{GDF11 and GDF15}

Growth differentiation factors (GDFs), including GDF11 and GDF15, belong to the TGF $\beta$ protein superfamily. They share homeostatic and metabolic regulation functions with TGF $\beta$ family members (such as myostatin) and bone morphogenic proteins (BMPs). Furthermore, they are both associated with regulation of skeletal muscle function and aging.

GDF11 has an analogical molecular structure and similar signaling pathways to myostatin [67]. However, GDF11 has different tissue distribution and biological effects. According to the GTEx database [68], GDF11 is broadly expressed in various tissues, including the brain, spleen, female reproductive organs, and digestive tract, while myostatin is predominantly expressed in the cervix, cerebellum, adrenal gland, skeletal muscle, aorta, and pituitary. Whereas myostatin's effects on skeletal muscle are well established, the perinatal lethality of GDF11 KO mice has restricted our knowledge of GDF11's role in skeletal muscle aging.

The current literature presents conflicting findings for the role of GDF11 in aging-related skeletal muscle phenotypes. GDF11 protein levels are higher in muscles from young mice compared to aged mice [69]. Further, Sinha et al. [69] found that administering recombinant GDF11 to aged mice reduced aging-associated DNA damage, improved mitochondrial and myofibrillar morphology, increased neuromuscular junction (NMJ) formation, improved endurance and grip strength, and improved muscle regeneration. However, Egerman et al. [70] reported conflicting results. After finding that the previously used reagents for GDF11 measurement were not specific and in contrast to the previous work, they found a trend for elevated circulating GDF11 in aged rats and older humans. Additionally, they found that GDF11 induced similar gene changes, signaling and inhibition of myoblast differentiation as myostatin. Finally, they demonstrated that GDF11 inhibits rather than helps muscle regeneration $[71,70]$. This has been further confirmed by other laboratories that have shown skeletal muscle atrophy [72] and impaired skeletal muscle regeneration [73] following recombinant GDF11 administration. Furthermore, administration of a GDF11/myostatin inhibitory peptide (GDF11PRO-Fc) induces skeletal muscle hypertrophy [74].

GDF15, also known as macrophage inhibitory cytokine 1 (MIC-1), traditionally has been categorized as a member of the
TGF $\beta$ superfamily and has also been investigated for its effects on skeletal muscle. Recent studies have identified glial cell linederived neurotrophic factor (GDNF) family receptor alpha like (GFRAL) as a receptor for GDF15 and thus raised the possibility that GDF15 shares similar actions to the GDNF-like growth factor family $[75,76]$. The Shong group proposed that GDF15 is a myomitokine, released in response to activation of the mitochondrial unfolded protein response, that beneficially regulates systemic energy expenditure [77,78]. Moon et al. [79] recently reported that Mendelian randomization analysis showed a causal effect of reduced GDF15 levels in human blood samples resulting in increased body weight and inflammation. The administration of recombinant GDF15 protein has an anti-obesity effect in mice $[80,81]$. In contrast to studies proposing beneficial effects of GDF15 on body mass, Lerner et al. [82] reported that GDF15 is a cytokine secreted from tumors that drives cancer cachexia. Furthermore, administration of GDF15 neutralizing antibodies prevents cancer and GDF-11-induced cachexia [83]. Consistent with this, Suriben et al. [84] found an inhibitory antibody raised against the GFRAL extracellular domain also prevented tumor-induced weight loss. However, most of these studies show the weight loss to be primarily driven by a loss in adipose tissue, consistent with the low expression of GFRAL in skeletal muscle (as measured in the GTEx database). Although GDF15 has been shown to be released from muscle and generates a negative caloric balance, more studies are required to test if it plays a causative role in muscular atrophy or sarcopenia.

\section{GUT MICROBIOTA AND MUSCLE AGING}

Recent studies reported that the diversity and composition of gut microbiome - the entire set of microorganisms residing in the digestive system of the host - could be altered significantly with aging $[85,86]$. Age-associated alterations of the gut microbiome might be related to decreased anabolic stimuli-induced muscle protein synthesis (i.e., AR) and chronic inflammation, which affects all aspects of skeletal muscle, including metabolism and physical performance [87-89]. The concept of an aging-related "leaky gut," whereby elderly hosts have abnormally increased gut mucosa permeability, suggests that the pro-inflammatory signals from the gut microbiome can enter the bloodstream and cause chronic low grade inflammation in the elderly [90]. If true, this may also be an avenue by which the age-associated changes in the gut microbiome may affect skeletal muscle.

Another possible candidate linking the gut-muscle axis to 
skeletal muscle homeostasis is gut microbiota-produced metabolites. Gut microbiota produce many metabolites, including short-chain fatty acids, that regulate host metabolism and inflammation [87]; imidazole propionate, which triggers insulin resistance [91]; indoxyl sulfate, which may be a cause of muscle atrophy [92]; and urolithin A (UA), which enhances mitophagy in skeletal muscle [42]. Thus, these findings suggest that metabolites affecting pathways thought to influence skeletal muscle homeostasis are produced by microbiota and are able to consequently influence host homeostasis independent of microbiota penetration of the intestinal lining and subsequent inflammation.

Specific studies have investigated the effect of manipulations of the gut microbiome on skeletal muscle. For example, Lahiri et al. [93] reported that germ-free mice harbor a muscular atrophy phenotype in comparison with pathogen-free mice. Germfree mice have increased expression of muscular atrophy proteins (e.g., atrogin-1 and muscle RING finger 1 [MuRF-1]), reduced expression of IGF-1, and reduced expression of serum choline, the precursor for acetylcholine, an essential neurotransmitter in the NMJ. Administration of gut microbiota from pathogen-free mice to germ-free mice and short-chain fatty acids could improve atrophy status, including muscle mass, as well as gene expression and biomarkers [93], thus implicating the bacterial and bacterially-derived metabolites in muscular atrophy. In agreement with Lahiri et al. [93], treatment with the antibiotic metronidazole, which alters the gut microbiota by favoring recolonization with Proteobacteria and Erysipelotrichales, induced muscle atrophy in mice [94]. Interestingly, Blacher et al. [95] recently demonstrated that antibiotics eliminating gut microbiota impaired muscular function in a murine model of amyotrophic lateral sclerosis (Sod1-G93A mice) and further that gut microbiota could be a chemical factory producing favorable $\mathrm{NAD}^{+}$precursors for host de novo $\mathrm{NAD}^{+}$synthesis. In their study, the administration of an engineered Escherichia coli, defective in $\mathrm{NAD}^{+}$generation, decreased grip endurance versus wild-type $E$. coli, whereas recolonization of antibiotic-treated mice with Akkermansia muciniphila increased levels of the $\mathrm{NAD}^{+}$precursor, NAM, increased neuromuscular function, and extended the lifespan of Sod1-G93A mice. Additionally, two recent review articles discussed the potential connections and mechanisms between the gut microbiome and muscle aging $[87,96]$ in more detail. In summary, the gut microbiome is a potential target for sarcopenia.

Hereby, we have covered issues related to muscle aging and sarcopenia. In summary, during the aging process, there are transitions of muscle fiber-type (a gradual decrease of both type

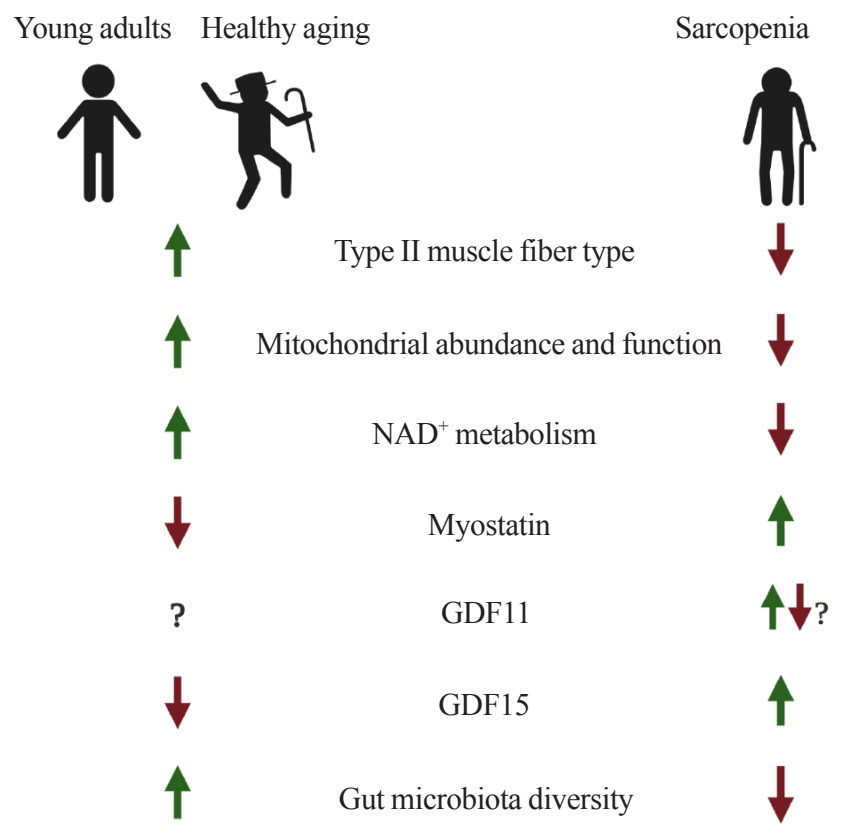

Fig. 1. Potential factors underlying muscle aging. NAD ${ }^{+}$, nicotinamide adenine dinucleotide; GDF, growth differentiation factor.

II fiber number and size), mitochondrial dysfunction, perturbed $\mathrm{NAD}^{+}$metabolism, and altered expressions of myokines such as myostatin, GDF11, and GDF15. Also, the composition of gut microflora and their derived metabolites, mediating the gutmuscle axis, are remodeled with age (Fig. 1).

\section{THERAPEUTIC STRATEGIES FOR MUSCLE AGING}

\section{Anabolic resistance and amino acids}

$\mathrm{AR}$, as described above, is defined by a diminished muscle protein synthetic rate following anabolic stimulation such as amino acids, muscle contraction, or anabolic hormones and is often observed with aging $[17,18,20,97,98]$. Thus theoretically, overcoming AR by supplementing with anabolic stimulants like essential amino acids (EAA) and resistance exercise are recommended avenues to combat sarcopenia $[99,100]$. However, despite efforts, they have yet to yield highly effective outcomes that correct all the effects of sarcopenia $[101,102]$. These findings indicate that sarcopenia could be composed of several subclasses of diseases originated by distinct internal (intramuscular) or external (systemic) triggers. To overcome AR and to develop novel therapeutics for sarcopenia, multi-omics analyses including not only genome, transcriptome and proteome but also metabolome and floxome (complete set of metabolic fluxes) have to be explored [18,103]. 


\section{Exercise mimetics}

As mentioned above, the best therapeutic option for sarcopenia is the combination of a regular exercise program and EAA supplementation. However, some patients cannot conduct regular exercise to maintain muscle protein synthesis and mass. For instance, patients with severe sarcopenia, severe frailty, hip fracture, congenital neuromuscular diseases, and those in intensive care are not able to reap the benefits of regular exercise. To help those patients who cannot perform enough physical activity to maintain muscle mass, so-nicknamed "exercise mimetics" or "exercise in a pill" pharmaceuticals are the only available therapeutic strategy to receive some of the effects of exercise in these populations.

Although a single pharmaceutical has not been identified that can replicate all the benefits of exercise, studies have examined the benefits of activating one or multiple signaling pathways associated with exercise. One molecular target that mediates the effect of exercise is the nuclear receptor peroxisome proliferator-activated receptor delta (PPAR $\delta$, also known as PPAR $\beta$ ). Narkar et al. [104] demonstrated that overexpression of PPAR $\delta$ and administration of the PPAR $\delta$ agonist GW501516 increased expression of genes associated with mitochondrial content including Ucp 3, Cpt1b, and Pdk4. When used in combination with exercise, GW50156 increased oxidative myofibers and running endurance in adult mice. However, overexpression of $\operatorname{PPAR} \delta$ alone does not reduce muscle wasting in mice in response to spinal cord transection [105]. Other reports suggest that GW501516 improves skeletal muscle mass in mouse models of muscular dystrophy [106] but has no effect on muscle mass in rats [107]. Furthermore, trials with GW501516 were discontinued due to preclinical data showing rapid induction of cancer in multiple organs [108]. Mitobridge (Boston, MA, USA) and Astellas (Tokyo, Japan) announced that their PPAR $\delta$ agonist ASP0367 (also known as MA-0211), which is being developed for the treatment of primary mitochondrial myopathies, has recently been granted fast track designation by the U.S. Food and Drug Administration (FDA) (Table 2). Therefore, PPAR $\delta$ agonists may prove beneficial in individuals suffering from sarcopenia through improved mitochondrial function and maintenance of oxidative type I myofibers, but may not prevent atrophy.

Another potential therapeutic avenue for attenuating sarcopenia is pharmacological activation of the exercise activatable $[109,110]$ and cellular energy sensor 5'-AMP-activated protein kinase (AMPK). This has been reviewed in detail elsewhere [111]. Briefly, mice with germline elimination of the AMPK structural subunit $\beta 2$ and muscle-specific ablation of the structural ( $\beta 1$ and $\beta 2$ ) and catalytic subunits (a1 and a2) of AMPK have decreased exercise capacity, decreased muscle function, and atrophied/damaged myofibers $[112,113]$ that is exacerbated with age [114]. However, other studies have found contrasting evidence whereby expression of a dominant-negative AMPK and loss of AMPK a1 and a 2 subunits elicited larger extensor digitorum longus muscle and larger myotubes in vitro $[115,116]$, respectively. This may partially be explained by differences in tissue specificity of AMPK-KO models (i.e., skeletal only or heart and skeletal muscle elimination) and the conflicting regulation of skeletal myogenesis via AMPK's known positive regulation of mitochondrial function and autophagy versus the negative regulation of protein synthesis via direct inhibition of mTOR signaling [117]. 5-Aminoimidazole-4-carboxamide ribonucleotide (AICAR), which is a cell-permeable precursor to 5-amino-4-imidazole carboxamide ribonucleoside 5'-phosphate (ZMP), an allosteric activator of AMPK, increases mitochondrial content in wild-type mice [104,118] but does not increase muscle mass in wild-type or MSTN-KO mice [119]. Interestingly, it does attenuate deficits in muscle in mouse models of muscular dystrophy without affecting myofiber size [120,121] and prevents muscle loss in mouse models of cancer cachexia [122]. Furthermore, A-769662 - a direct allosteric activator of AMPK $\beta 2$ - and AICAR synergistically attenuated interferon gamma (IFNy) and tumor necrosis factor- $\alpha$ (TNFa)-induced myotube atrophy in vitro. Evidence to date suggests that AMPK activators are effective at improving mitochondrial and muscle function while only maintaining skeletal muscle size in models of muscular dystrophy and cancer cachexia. New AMPK activators are continually being produced that have increased isoform specificity $[123,124]$ and may provide further insights into tissue-specific effects of AMPK activation and their effects on maintenance or improvement of skeletal muscle. SIRT1 activators, including $\mathrm{NAD}^{+}$boosters and resveratrol, which we describe separately, also induce exercise signaling. Absence of skeletal muscle SIRT1 reduces mitochondrial content in skeletal muscle [125]. The Auwerx group and others have demonstrated that resveratrol supplementation increases mitochondrial biogenesis, energy expenditure, and endurance exercise in mice [126]. Furthermore, it improves mitochondrial function and lipid and glucose homeostasis in obese men [127]. These results suggest that SIRT1 activation may stimulate mitochondrial content and presumably age-related decreases in skeletal muscle mitochondrial function.

In addition to the above pathways, transcription factors such 
Table 2. Summary of Drug Candidates Undergoing Preclinical and Clinical Trials in Muscle Wasting Diseases

\begin{tabular}{|c|c|c|c|c|}
\hline Drug & Type/MoA & Indication and clinical trial (NCT no.) & Developer/Sponsor & Note \\
\hline $\begin{array}{r}\text { Bimagrumab } \\
\text { (BYM338) }\end{array}$ & $\begin{array}{l}\text { Human monoclonal antibody } \\
\text { Activin receptor type } 2 \mathrm{~B} \\
\text { antagonist }\end{array}$ & $\begin{array}{l}\text { Sporadic inclusion body myositis } \\
\text { (sIBM) [NCT02573467] } \\
\text { Muscle wasting (atrophy) after hip } \\
\text { fracture surgery [NCT02152761] } \\
\text { Chronic obstructive pulmonary disease } \\
\text { (COPD) patients with cachexia } \\
\text { [NCT01669174] }\end{array}$ & $\begin{array}{l}\text { Novartis AG } \\
\text { MorphoSys AG }\end{array}$ & $\begin{array}{l}\text { Bimagrumab withdrawn from Phase } 2 \\
\text { trials for sIBM } \\
\text { PMID: } 25381300\end{array}$ \\
\hline $\begin{array}{l}\text { Trevogrumab } \\
\text { (REGN1033) }\end{array}$ & $\begin{array}{l}\text { Human monoclonal antibody } \\
\text { Myostatin or activin blocker }\end{array}$ & $\begin{array}{l}\text { Sarcopenia [NCT01963598] } \\
\text { sIBM [NCT03710941] }\end{array}$ & $\begin{array}{l}\text { Regeneron } \\
\text { Pharmaceuticals } \\
\text { Inc./Sanofi SA }\end{array}$ & $\begin{array}{l}\text { Regeneron canceled clinical trial of } \\
\text { REGN2477 and REGN1033 for } \\
\text { inclusion body myositis }\end{array}$ \\
\hline $\begin{array}{l}\text { Garetosmab } \\
\text { (REGN2477) }\end{array}$ & $\begin{array}{l}\text { Human monoclonal antibody } \\
\text { Myostatin or activin blocker }\end{array}$ & $\begin{array}{l}\text { sIBM [NCT03710941] } \\
\text { Fibrodysplasia ossificans progressiva } \\
\text { (FOP) [NCT03188666] }\end{array}$ & $\begin{array}{l}\text { Regeneron } \\
\text { Pharmaceuticals } \\
\text { Inc./Sanofi SA }\end{array}$ & $\begin{array}{l}\text { Nearly } 90 \% \text { reduction in formation of } \\
\text { new lesions in patients with FOP }\end{array}$ \\
\hline ACE-083 & $\begin{array}{l}\text { Follistatin-based fusion } \\
\text { protein } \\
\text { Myostatin or activin blocker }\end{array}$ & $\begin{array}{l}\text { Facioscapulohumeral muscular } \\
\text { dystrophy } \\
\text { Charcot-Marie-Tooth (CMT) disease } \\
\text { [NCT03943290] }\end{array}$ & Acceleron & $\begin{array}{l}\text { ACE- } 083 \text { in patients with CMT did not } \\
\text { show functional improvement in the } \\
\text { Phase } 2 \text { trial. }\end{array}$ \\
\hline ACE-2494 & $\begin{array}{l}\text { GDF ligand trapping peptide } \\
\text { Myostatin or activin blocker }\end{array}$ & $\begin{array}{l}\text { Healthy volunteers (for safety) } \\
\text { [NCT03478319] }\end{array}$ & Acceleron & $\begin{array}{l}\text { In April 2019, Acceleron discontinued } \\
\text { ACE-2494, which was in Phase I } \\
\text { development. }\end{array}$ \\
\hline $\begin{array}{r}\text { Domagrozumab } \\
(\text { PF06252616) }\end{array}$ & $\begin{array}{l}\text { Monoclonal anti-myostatin } \\
\text { antibody } \\
\text { Myostatin or activin blocker }\end{array}$ & DMD [NCT02310763] & Pfizer & $\begin{array}{l}\text { Pfizer announced, in August 2018, that } \\
\text { the study did not meet the primary } \\
\text { efficacy endpoint }\end{array}$ \\
\hline $\begin{array}{l}\text { Reldesemtiv } \\
\quad(\mathrm{CK}-212710)\end{array}$ & $\begin{array}{l}\text { Small molecule } \\
\text { Slowing the rate of calcium } \\
\text { release from the regulatory } \\
\text { troponin complex }\end{array}$ & $\begin{array}{l}\text { Mobility limitation in old age } \\
\text { [NCT03065959] } \\
\text { Amyotrophic lateral sclerosis (ALS) } \\
\text { [NCT03160898], spinal muscular } \\
\text { atrophy [NCT02644668] }\end{array}$ & Cytokinetics/Astella & $\begin{array}{l}\text { European Medicines Agency (EMA) } \\
\text { granted orphan drug status to } \\
\text { Cytokinetics' Reldesemtiv for the } \\
\text { treatment of ALS. }\end{array}$ \\
\hline $\begin{array}{l}\text { ARM210 } \\
\text { (S48168) }\end{array}$ & $\begin{array}{l}\text { Small molecule } \\
\text { Binding to leaky RyR channels } \\
\text { and repairs the leak }\end{array}$ & RYR-1 myopathy [NCT04141670] & $\begin{array}{l}\text { ARMGO Pharma } \\
\text { Inc. }\end{array}$ & $\begin{array}{l}\text { In } 2018 \text {, the FDA granted orphan drug } \\
\text { designation to ARMGO for ARM } 210 \\
\text { as a potential treatment for patients } \\
\text { with RYR1-RM. }\end{array}$ \\
\hline AVGN7 & $\begin{array}{l}\text { rAAV6 (gene therapy) } \\
\text { rAAV6:Smad7 contains a gene } \\
\text { called SMAD7 }\end{array}$ & IBM, cancer cachexia, etc. & AAVogen Inc. & In preclinical development \\
\hline $\begin{array}{l}\text { Ligandrol } \\
\text { (VK5211, } \\
\text { LGD-4033) }\end{array}$ & $\begin{array}{l}\text { Small molecule } \\
\text { Nonsteroidal oral selective } \\
\text { androgen receptor modulator } \\
\text { (SARM) }\end{array}$ & $\begin{array}{l}\text { Acute hip fracture study in patients } 65 \\
\text { years or greater [NCT02578095] }\end{array}$ & Viking Therapeutics & $\begin{array}{l}\text { Phase } 2 \text { study of VK } 5211 \text { in patients } \\
\text { recovering from hip fracture reported } \\
\text { (1) dose-dependent increases in lean } \\
\text { body mass and (2) } 20 \text {-meter increase } \\
\text { in } 6 \text { MWD over placebo }\end{array}$ \\
\hline GSK2881078 & $\begin{array}{l}\text { Small molecule } \\
\text { SARM }\end{array}$ & $\begin{array}{l}\text { Healthy older men and postmenopausal } \\
\text { women [NCT02567773] } \\
\text { Male subjects and postmenopausal } \\
\text { female subjects with COPD and } \\
\text { muscle weakness [NCT03359473] }\end{array}$ & Glaxo-Smith-Kline & $\begin{array}{l}\text { GSK2881078 promotes a dose- } \\
\text { dependent increase in lean body mass } \\
\text { in healthy older men and women }\end{array}$ \\
\hline $\begin{array}{l}\text { Enobosarm } \\
\text { (MK-2866, } \\
\text { ostarine) }\end{array}$ & $\begin{array}{l}\text { Small molecule } \\
\text { SARM }\end{array}$ & $\begin{array}{l}\text { Subjects with non-small cell lung } \\
\text { cancer [NCT01355497 \& } \\
\text { NCT01355484] }\end{array}$ & GTx Inc. & $\begin{array}{l}\text { Clinical trials failed to meet the overall } \\
\text { criteria for the co-primary responder } \\
\text { endpoints of lean body mass and } \\
\text { physical function }\end{array}$ \\
\hline
\end{tabular}

(Continued to the next page) 


\begin{tabular}{|c|c|c|c|c|}
\hline Drug & Type/MoA & Indication and clinical trial (NCT no.) & Developer/Sponsor & Note \\
\hline $\begin{array}{l}\text { Nicotinamide } \\
\text { riboside }\end{array}$ & $\begin{array}{l}\text { Small molecule } \\
\text { NAD+ booster }\end{array}$ & $\begin{array}{l}\text { Aging male subjects [NCT02950441] } \\
\text { Sarcopenia/frailty in chronic kidney } \\
\text { disease [NCT03579693] }\end{array}$ & $\begin{array}{l}\text { University of } \\
\text { Birmingham } \\
\text { University of } \\
\text { Washington }\end{array}$ & $\begin{array}{l}\text { Phase } 2 \text {, no results posted } \\
\text { Phase 2, recruiting }\end{array}$ \\
\hline $\begin{array}{l}\text { Nicotinic acid } \\
\text { (Niacin) }\end{array}$ & $\begin{array}{l}\text { Small molecule } \\
\text { NAD + booster }\end{array}$ & $\begin{array}{l}\text { Myopathy patients [NCT03973203] } \\
\text { Early-stage mitochondrial myopathy } \\
\text { patients [NCT04538521] } \\
\text { Older adults [NCT03325491] }\end{array}$ & $\begin{array}{l}\text { University of } \\
\text { Helsinki }\end{array}$ & $\begin{array}{l}\text { Muscle strength and mitochondrial } \\
\text { biogenesis increased in all subjects } \\
\text { Active, not recruiting } \\
\text { Failed to recruit enough participants }\end{array}$ \\
\hline $\begin{array}{l}\text { ASP0367 } \\
\text { (MA-0211) }\end{array}$ & $\begin{array}{l}\text { Small molecule } \\
\text { PPAR } \delta \text { agonist }\end{array}$ & $\begin{array}{l}\text { Pediatric male patients with DMD } \\
\text { [NCT04184882] }\end{array}$ & Mitobridge/Astellas & $\begin{array}{l}\text { FDA grants fast track designation for } \\
\text { development for the treatment of } \\
\text { primary mitochondrial myopathies }\end{array}$ \\
\hline Urolithin A & $\begin{array}{l}\text { Small molecule } \\
\text { Mitophagy enhancer }\end{array}$ & $\begin{array}{l}\text { Healthy adults, older adults } \\
\text { [NCT04160312] }\end{array}$ & Amazentis SA & $\begin{array}{l}\text { Urolithin A is safe and improves } \\
\text { mitochondrial and cellular health in } \\
\text { humans. }\end{array}$ \\
\hline Elamipretide & $\begin{array}{l}\text { Peptide } \\
\text { Mitochondrial enhancer }\end{array}$ & $\begin{array}{l}\text { Primary mitochondrial myopathy sub- } \\
\text { jects [NCT03323749] }\end{array}$ & $\begin{array}{l}\text { Stealth } \\
\text { BioTherapeutics }\end{array}$ & $\begin{array}{l}\text { The study did not record its essential } \\
\text { endpoints of changes in the } 6 \mathrm{MWD} \\
\text { and primary mitochondrial myopathy } \\
\text { symptom assessment total fatigue } \\
\text { score. }\end{array}$ \\
\hline
\end{tabular}

MoA, mode-of-action; NCT, National Clinical Trial; GDF, growth differentiation factor; MAS, mitochondrial assembly; SARA-INT, Sarcopenia, A Double-blind Placebo Controlled Randomized INTerventional Clinical Trial; RyR, ryanodine receptor; FDA, U.S. Food and Drug Administration; RYR1-RM, ryanodine receptor type 1-related myopathies; 6MWD, 6-minute walk distance; PPAR $\delta$, peroxisome proliferator-activated receptor delta.

as PPAR $\alpha / \delta, E R R \alpha / \gamma$, and nuclear respiratory factor-1/-2 (NRF$1 /-2$ ) contribute to the control of nuclear DNA-encoded mitochondrial gene expression $[38,128]$, and thus any agonist or activator targeting those transcription factors may induce exerciselike effects. Although the potential of ERR $\gamma$ agonists has not yet been validated in vivo, GSK4716, an ERR $\gamma$ agonist, robustly upregulates genes involved in mitochondrial biogenesis and metabolism [129]. Interestingly, a recent human study administered UA for 4 weeks and showed that the muscle transcriptome of UA-given elderly individuals demonstrated a positively enriched mitochondrial gene-set profile compared to the placebo control that is similar to transcriptome profiles of muscle from active versus sedentary individuals [43]. Although exercise mimetics cannot produce all the beneficial effects of regular exercise and there is also a risk of their abuse by athletes, mimetics may prove beneficial in certain patient populations, for whom they may be the only option, but additional studies are required.

\section{Myokines and monoclonal antibodies}

One of most intensively studied therapeutic targets of muscle atrophy is myostatin, a well-known myokine having negative effects on muscle regeneration and mass [130]. Although many candidates (mostly monoclonal antibodies or soluble receptors) blocking myostatin-activin receptor signaling pathway have failed or been withdrawn from clinical trials, it is still one of the most promising and pursued pipelines. For instance, bimagrumab (BYM338), a human monoclonal antibody antagonizing the activin receptor type $2 \mathrm{~B}$, was developed by MorphoSys AG (Munich, Germany) and Novartis (Basel, Switzerland) and improved lean body mass, muscle volume, and 6-minute walk test results, but was withdrawn from phase 2 clinical trials for sporadic inclusion body myositis (sIBM) (Table 2, Fig. 2) [131]. Unfortunately, other monoclonal antibodies or peptides targeting myostatin-activin receptor signaling pathways, such as trevogrumab (REGN1033, Regeneron Pharmaceuticals Inc. and Sanofi SA), garetosmab (REGN2477, Regeneron Pharmaceuticals Inc. and Sanofi SA), ACE-083 (Acceleron), ACE-2494 (Acceleron), RG6206 (RO7239361, Roche and Genentech), domagrozumab (PF06252616, Pfizer), and sarconeos (BIO101, Biophytis) have not yet reached the primary endpoint (Table 2).

As aforementioned, recent studies have discovered several potential candidates associated with muscle atrophy or aging, such as GDF11 and GDF15. Recently, several biotechnology and pharmaceutical companies have adopted new strategies to 


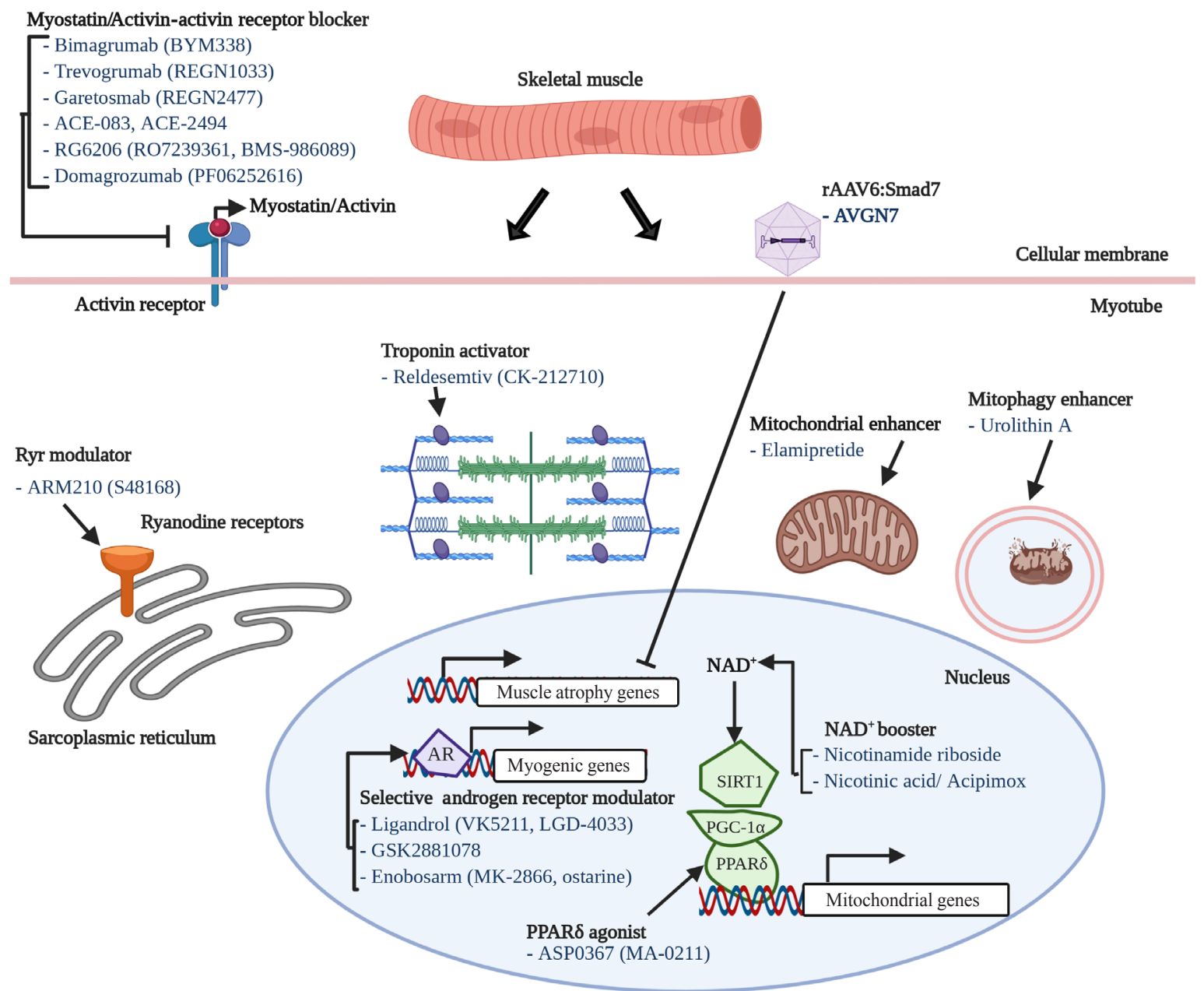

Fig. 1. Potential factors underlying muscle aging. AR, anabolic resistance; NAD ${ }^{+}$, nicotinamide adenine dinucleotide; GDF, growth differentiation factor.

develop novel therapeutics such as a dual agonist, a triple agonist, dual antagonists, and so forth $[132,133]$. Those kinds of concepts must also be explored in the field of muscle aging.

\section{NAD $^{+}$boosters}

Herein, we define $\mathrm{NAD}^{+}$boosters as any therapeutic preserving subcellular $\mathrm{NAD}^{+}$content through increasing/maintaining the $\mathrm{NAD}^{+}$de novo biosynthesis pathway and salvage cycles, or the inhibition of $\mathrm{NAD}^{+}$consumption enzymes. NAM, NMN, NR, and nicotinic acid (NA, also known as niacin) are the most intensively studied $\mathrm{NAD}^{+}$boosters and are integral to the $\mathrm{NAD}^{+}$ biosynthesis pathways [52]. We have reported that oral supplementation of NR restored the $\mathrm{NAD}^{+}$pool, improved the muscle stem cell pool, and improved muscle function in aged mice and a murine model of Duchenne muscular dystrophy (DMD; i.e., $m d x$ mice) [51,55]. Consistent with these findings, Elhassan et al. [53] reported that NR supplementation $(1,000 \mathrm{mg} /$ day $)$ increased $\mathrm{NAD}^{+}$in skeletal muscle of older adults without obesity (median 75 years old; body mass index $<30 \mathrm{~kg} / \mathrm{m}^{2}$ ) and decreased circulating levels of pro-inflammatory cytokines. In contrast, Dollerup et al. [134], administered 2,000 mg/day of NR to obese men and did not observe any alterations in $\mathrm{NAD}^{+}$ levels or mitochondrial gene expression in men. Mills et al. [135] demonstrated that 12-month administration of NMN increased skeletal muscle $\mathrm{NAD}^{+}$levels, elevated physical activity, increased energy expenditure, improved mitochondrial respiration, decreased age-associated weight gain, improved eye function and increased bone mineral density. Guo et al. [136] found that NAM protected streptozotocin-induced diabetic mice from muscle atrophy. More than 50 trials of $\mathrm{NAD}^{+}$boosters are listed on the U.S. National Library of Medicine Clinical Trials website (https://clinicaltrials.gov/). The outcomes of ongoing and planned 
human trials will be critical to confirming or refuting the therapeutic potential of $\mathrm{NAD}^{+}$boosters for sarcopenia.

\section{Sarcopenia pipeline}

We have described several potential therapeutics for sarcopenia from recent publications. Nineteen drug candidates in development for treating sarcopenia are summarized in Table 2. Their modes-of-action are also included in Table 2, Fig. 2. Eight of the 19 drug candidates are monoclonal antibodies or peptides targeting myostatin or the activin receptor, eight are small molecules targeting the androgen receptor, ryanodine receptors (RyRs), fast skeletal muscle troponin complex (TnT/TnI/TnC), PPAR $\delta$, or mitophagy activation, and one is a peptide targeting mitochondria function.

\section{CONCLUSIONS}

Nowadays, in the context of increasing average life expectancy, sarcopenia and frailty deserve more attention from researchers. Although many international and regional organizations have provided guidelines for assessing sarcopenia, countries still need to develop their own diagnostic toolkits following the anthropometric characteristics and medical capabilities of each country.

Although many recent studies have expanded our understanding of sarcopenia, these findings were primarily from animal models or correlative biomarkers in the human blood and feces, indicating the limitation of our knowledge on sarcopenia. Performing randomized control trials in humans to test these therapeutics and modalities are critical and the lack thereof could be a reason for the inconsistent results between studies. However, the difficulty in obtaining muscle biopsies from those suffering from muscle atrophy may mean we must develop non-invasive or minimally invasive methods. For instance, fluxomics which can measure markers of muscle protein synthetic rate from saliva, urine, or blood of human patients and magnetic resonance spectroscopy, which monitors mitochondrial oxidative capacity, may be suitable methods for patients suffering from sarcopenia [137-140]. In addition, longitudinal monitoring studies spanning age, gender, and race have to be done to find early predictive biomarkers for the risk of sarcopenia.

In addition to non-invasive human studies, animal modelbased studies also have to be performed using modern multiomics technology combined with computational analyses to address underlying cellular and molecular mechanisms, categorize sarcopenia into subclass based on revealed hidden signatures, validate biomarkers, and apply precision medicine for the prevention and treatment of sarcopenia.

\section{CONFLICTS OF INTEREST}

No potential conflict of interest relevant to this article was reported.

\section{ACKNOWLEDGMENTS}

This study was supported by the Basic Science Research Program through the National Research Foundation of Korea (NRF) funded by the Ministry of Science and ICT (NRF-2020R1A2C2010964) to Dongryeol Ryu and grants from the Canadian Institutes of Health Research (MOP 159455) and the Natural Sciences and Engineering Research Council of Canada (RGPIN 2018-06838, DGECR 2018-00012) to Keir J. Menzies. Alexander E. Green is the recipient of a uOttawa Eric Poulin Centre for Neuromuscular Disease (CNMD) Scholarship in Translational Research (STaR) Award which is supported by the University of Ottawa Brain and Mind Research Institute (uOBMRI).

\section{ORCID}

Tam Dao https://orcid.org/0000-0001-6611-0497

Alexander E. Green https://orcid.org/0000-0002-4311-7212

Keir J. Menzies https://orcid.org/0000-0002-1873-8500

Dongryeol Ryu https://orcid.org/0000-0001-5905-6760

\section{REFERENCES}

1. Population Division, Department of Economic and Social Affairs, United Nations. World population aging, 2019 highlights. New York: United Nations; 2019. p. 11-4.

2. Kim G, Kim JH. Impact of skeletal muscle mass on metabolic health. Endocrinol Metab (Seoul) 2020;35:1-6.

3. Jung HW. Visualizing domains of comprehensive geriatric assessments to grasp frailty spectrum in older adults with a radar chart. Ann Geriatr Med Res 2020;24:55-6.

4. Cruz-Jentoft AJ, Sayer AA. Sarcopenia. Lancet 2019;393: 2636-46.

5. Chen X, Mao G, Leng SX. Frailty syndrome: an overview. Clin Interv Aging 2014;9:433-41.

6. Anker SD, Morley JE, von Haehling S. Welcome to the ICD-10 code for sarcopenia. J Cachexia Sarcopenia Muscle 2016;7:512-4. 
7. Baumgartner RN, Koehler KM, Gallagher D, Romero L, Heymsfield SB, Ross RR, et al. Epidemiology of sarcopenia among the elderly in New Mexico. Am J Epidemiol 1998;147:755-63.

8. Lauretani F, Russo CR, Bandinelli S, Bartali B, Cavazzini C, Di Iorio A, et al. Age-associated changes in skeletal muscles and their effect on mobility: an operational diagnosis of sarcopenia. J Appl Physiol (1985) 2003;95:1851-60.

9. Cruz-Jentoft AJ, Baeyens JP, Bauer JM, Boirie Y, Cederholm T, Landi F, et al. Sarcopenia: European consensus on definition and diagnosis. Report of the European Working Group on sarcopenia in older people. Age Ageing 2010;39:412-23.

10. Cruz-Jentoft AJ, Bahat G, Bauer J, Boirie Y, Bruyere O, Cederholm T, et al. Sarcopenia: revised European consensus on definition and diagnosis. Age Ageing 2019;48:16-31.

11. Chen LK, Woo J, Assantachai P, Auyeung TW, Chou MY, Iijima K, et al. Asian Working Group for sarcopenia: 2019 consensus update on sarcopenia diagnosis and treatment. J Am Med Dir Assoc 2020;21:300-7.

12. Fielding RA, Vellas B, Evans WJ, Bhasin S, Morley JE, Newman AB, et al. Sarcopenia: an undiagnosed condition in older adults. Current consensus definition: prevalence, etiology, and consequences. International Working Group on Sarcopenia. J Am Med Dir Assoc 2011;12:249-56.

13. McLean RR, Kiel DP. Developing consensus criteria for sarcopenia: an update. J Bone Miner Res 2015;30:588-92.

14. Iannuzzi-Sucich M, Prestwood KM, Kenny AM. Prevalence of sarcopenia and predictors of skeletal muscle mass in healthy, older men and women. J Gerontol A Biol Sci Med Sci 2002;57:M772-7.

15. Liu X, Hao Q, Hou L, Xia X, Zhao W, Zhang Y, et al. Ethnic groups differences in the prevalence of sarcopenia using the AWGS criteria. J Nutr Health Aging 2020;24:665-71.

16. Pacifico J, Geerlings MAJ, Reijnierse EM, Phassouliotis C, Lim WK, Maier AB. Prevalence of sarcopenia as a comorbid disease: a systematic review and meta-analysis. Exp Gerontol 2020;131:110801.

17. Cuthbertson D, Smith K, Babraj J, Leese G, Waddell T, Atherton P, et al. Anabolic signaling deficits underlie amino acid resistance of wasting, aging muscle. FASEB J 2005; 19:422-4.

18. Kim IY, Park S, Jang J, Wolfe RR. Understanding muscle protein dynamics: technical considerations for advancing sarcopenia research. Ann Geriatr Med Res 2020;24:157-65.

19. Timmerman KL, Lee JL, Fujita S, Dhanani S, Dreyer HC, Fry CS, et al. Pharmacological vasodilation improves insu- lin-stimulated muscle protein anabolism but not glucose utilization in older adults. Diabetes 2010;59:2764-71.

20. Colleluori G, Aguirre L, Phadnis U, Fowler K, ArmamentoVillareal R, Sun Z, et al. Aerobic plus resistance exercise in obese older adults improves muscle protein synthesis and preserves myocellular quality despite weight loss. Cell Metab 2019;30:261-73.

21. Moore DR, Churchward-Venne TA, Witard O, Breen L, Burd NA, Tipton KD, et al. Protein ingestion to stimulate myofibrillar protein synthesis requires greater relative protein intakes in healthy older versus younger men. J Gerontol A Biol Sci Med Sci 2015;70:57-62.

22. Funai K, Parkington JD, Carambula S, Fielding RA. Age-associated decrease in contraction-induced activation of downstream targets of Akt $/ \mathrm{mTor}$ signaling in skeletal muscle. Am J Physiol Regul Integr Comp Physiol 2006;290:R1080-6.

23. Talbot J, Maves L. Skeletal muscle fiber type: using insights from muscle developmental biology to dissect targets for susceptibility and resistance to muscle disease. Wiley Interdiscip Rev Dev Biol 2016;5:518-34.

24. Lexell J. Human aging, muscle mass, and fiber type composition. J Gerontol A Biol Sci Med Sci 1995;50 Spec No:11-6.

25. Nilwik R, Snijders T, Leenders M, Groen BB, van Kranenburg J, Verdijk LB, et al. The decline in skeletal muscle mass with aging is mainly attributed to a reduction in type II muscle fiber size. Exp Gerontol 2013;48:492-8.

26. Short KR, Vittone JL, Bigelow ML, Proctor DN, CoenenSchimke JM, Rys P, et al. Changes in myosin heavy chain mRNA and protein expression in human skeletal muscle with age and endurance exercise training. J Appl Physiol (1985) 2005;99:95-102.

27. Klitgaard H, Zhou M, Schiaffino S, Betto R, Salviati G, Saltin B. Ageing alters the myosin heavy chain composition of single fibres from human skeletal muscle. Acta Physiol Scand 1990;140:55-62.

28. Lexell J, Downham DY. The occurrence of fibre-type grouping in healthy human muscle: a quantitative study of cross-sections of whole vastus lateralis from men between 15 and 83 years. Acta Neuropathol 1991;81:377-81.

29. Wallace DC. A mitochondrial paradigm of metabolic and degenerative diseases, aging, and cancer: a dawn for evolutionary medicine. Annu Rev Genet 2005;39:359-407.

30. Spinelli JB, Haigis MC. The multifaceted contributions of mitochondria to cellular metabolism. Nat Cell Biol 2018; 20:745-54.

31. Chan DC. Mitochondria: dynamic organelles in disease, 
aging, and development. Cell 2006;125:1241-52.

32. Lopez-Otin C, Blasco MA, Partridge L, Serrano M, Kroemer G. The hallmarks of aging. Cell 2013;153:1194-217.

33. Chabi B, Ljubicic V, Menzies KJ, Huang JH, Saleem A, Hood DA. Mitochondrial function and apoptotic susceptibility in aging skeletal muscle. Aging Cell 2008;7:2-12.

34. Lin MT, Beal MF. Mitochondrial dysfunction and oxidative stress in neurodegenerative diseases. Nature 2006;443:78795.

35. Migliavacca E, Tay SKH, Patel HP, Sonntag T, Civiletto G, McFarlane $\mathrm{C}$, et al. Mitochondrial oxidative capacity and $\mathrm{NAD}+$ biosynthesis are reduced in human sarcopenia across ethnicities. Nat Commun 2019;10:5808.

36. Rygiel KA, Picard M, Turnbull DM. The ageing neuromuscular system and sarcopenia: a mitochondrial perspective. J Physiol 2016;594:4499-512.

37. Lundt S, Zhang N, Wang X, Polo-Parada L, Ding S. The effect of NAMPT deletion in projection neurons on the function and structure of neuromuscular junction (NMJ) in mice. Sci Rep 2020;10:99.

38. Scarpulla RC, Vega RB, Kelly DP. Transcriptional integration of mitochondrial biogenesis. Trends Endocrinol Metab 2012;23:459-66.

39. Sun N, Youle RJ, Finkel T. The mitochondrial basis of aging. Mol Cell 2016;61:654-66.

40. Masiero E, Agatea L, Mammucari C, Blaauw B, Loro E, Komatsu M, et al. Autophagy is required to maintain muscle mass. Cell Metab 2009;10:507-15.

41. Pyo JO, Yoo SM, Ahn HH, Nah J, Hong SH, Kam TI, et al. Overexpression of Atg5 in mice activates autophagy and extends lifespan. Nat Commun 2013;4:2300.

42. Ryu D, Mouchiroud L, Andreux PA, Katsyuba E, Moullan N, Nicolet-Dit-Felix AA, et al. Urolithin A induces mitophagy and prolongs lifespan in C. elegans and increases muscle function in rodents. Nat Med 2016;22:879-88.

43. Andreux PA, Blanco-Bose W, Ryu D, Burdet F, Ibberson M, Aebischer $\mathrm{P}$, et al. The mitophagy activator urolithin $\mathrm{A}$ is safe and induces a molecular signature of improved mitochondrial and cellular health in humans. Nat Metab 2019;1: 595-603.

44. Fang EF, Hou Y, Palikaras K, Adriaanse BA, Kerr JS, Yang $\mathrm{B}$, et al. Mitophagy inhibits amyloid- $\beta$ and tau pathology and reverses cognitive deficits in models of Alzheimer's disease. Nat Neurosci 2019;22:401-12.

45. Eisenberg T, Abdellatif M, Schroeder S, Primessnig U, Stekovic S, Pendl T, et al. Cardioprotection and lifespan ex- tension by the natural polyamine spermidine. Nat Med 2016;22:1428-38.

46. Katsyuba E, Romani M, Hofer D, Auwerx J. NAD+ homeostasis in health and disease. Nat Metab 2020;2:9-31.

47. Gomes AP, Price NL, Ling AJ, Moslehi JJ, Montgomery $\mathrm{MK}$, Rajman L, et al. Declining $\mathrm{NAD}(+)$ induces a pseudohypoxic state disrupting nuclear-mitochondrial communication during aging. Cell 2013;155:1624-38.

48. Camacho-Pereira J, Tarrago MG, Chini CCS, Nin V, Escande $\mathrm{C}$, Warner GM, et al. CD38 dictates age-related NAD decline and mitochondrial dysfunction through an SIRT3dependent mechanism. Cell Metab 2016;23:1127-39.

49. Frederick DW, Loro E, Liu L, Davila A Jr, Chellappa K, Silverman IM, et al. Loss of NAD homeostasis leads to progressive and reversible degeneration of skeletal muscle. Cell Metab 2016;24:269-82.

50. Goody MF, Henry CA. A need for NAD+ in muscle development, homeostasis, and aging. Skelet Muscle 2018;8:9.

51. Zhang H, Ryu D, Wu Y, Gariani K, Wang X, Luan P, et al. $\mathrm{NAD}+$ repletion improves mitochondrial and stem cell function and enhances life span in mice. Science 2016;352: 1436-43.

52. Kang BE, Choi JY, Stein S, Ryu D. Implications of NAD+ boosters in translational medicine. Eur J Clin Invest 2020; 50:e13334.

53. Elhassan YS, Kluckova K, Fletcher RS, Schmidt MS, Garten A, Doig CL, et al. Nicotinamide riboside augments the aged human skeletal muscle NAD+ metabolome and induces transcriptomic and anti-inflammatory signatures. Cell Rep 2019;28:1717-28.

54. Tarrago MG, Chini CCS, Kanamori KS, Warner GM, Caride A, de Oliveira GC, et al. A potent and specific CD38 inhibitor ameliorates age-related metabolic dysfunction by reversing tissue NAD+ decline. Cell Metab 2018;27:108195.

55. Ryu D, Zhang H, Ropelle ER, Sorrentino V, Mazala DA, Mouchiroud L, et al. NAD+ repletion improves muscle function in muscular dystrophy and counters global PARylation. Sci Transl Med 2016;8:361ra139.

56. Claflin DR, Jackson MJ, Brooks SV. Age affects the contraction-induced mitochondrial redox response in skeletal muscle. Front Physiol 2015;6:21.

57. Lee SJ. Regulation of muscle mass by myostatin. Annu Rev Cell Dev Biol 2004;20:61-86.

58. McPherron AC, Lawler AM, Lee SJ. Regulation of skeletal muscle mass in mice by a new TGF-beta superfamily mem- 
ber. Nature 1997;387:83-90.

59. Amthor H, Macharia R, Navarrete R, Schuelke M, Brown $\mathrm{SC}$, Otto A, et al. Lack of myostatin results in excessive muscle growth but impaired force generation. Proc Natl Acad Sci U S A 2007;104:1835-40.

60. Schuelke M, Wagner KR, Stolz LE, Hubner C, Riebel T, Komen W, et al. Myostatin mutation associated with gross muscle hypertrophy in a child. N Engl J Med 2004;350:2682-8.

61. Hansen J, Brandt C, Nielsen AR, Hojman P, Whitham M, Febbraio MA, et al. Exercise induces a marked increase in plasma follistatin: evidence that follistatin is a contractioninduced hepatokine. Endocrinology 2011;152:164-71.

62. Chang YC, Liu HW, Chan YC, Hu SH, Liu MY, Chang SJ. The green tea polyphenol epigallocatechin-3-gallate attenuates age-associated muscle loss via regulation of miR-4865p and myostatin. Arch Biochem Biophys 2020;692:108511.

63. Bergen HR 3rd, Farr JN, Vanderboom PM, Atkinson EJ, White TA, Singh RJ, et al. Myostatin as a mediator of sarcopenia versus homeostatic regulator of muscle mass: insights using a new mass spectrometry-based assay. Skelet Muscle 2015;5:21.

64. Yarasheski KE, Bhasin S, Sinha-Hikim I, Pak-Loduca J, Gonzalez-Cadavid NF. Serum myostatin-immunoreactive protein is increased in 60-92 year old women and men with muscle wasting. J Nutr Health Aging 2002;6:343-8.

65. Ratkevicius A, Joyson A, Selmer I, Dhanani T, Grierson C, Tommasi AM, et al. Serum concentrations of myostatin and myostatin-interacting proteins do not differ between young and sarcopenic elderly men. J Gerontol A Biol Sci Med Sci 2011;66:620-6.

66. Hofmann M, Halper B, Oesen S, Franzke B, Stuparits P, Tschan H, et al. Serum concentrations of insulin-like growth factor-1, members of the TGF-beta superfamily and follistatin do not reflect different stages of dynapenia and sarcopenia in elderly women. Exp Gerontol 2015;64:35-45.

67. Schafer MJ, Atkinson EJ, Vanderboom PM, Kotajarvi B, White TA, Moore MM, et al. Quantification of GDF11 and myostatin in human aging and cardiovascular disease. Cell Metab 2016;23:1207-15.

68. GTEx Consortium. Human genomics. The Genotype-Tissue Expression (GTEx) pilot analysis: multitissue gene regulation in humans. Science 2015;348:648-60.

69. Sinha M, Jang YC, Oh J, Khong D, Wu EY, Manohar R, et al. Restoring systemic GDF11 levels reverses age-related dysfunction in mouse skeletal muscle. Science 2014;344: 649-52.
70. Egerman MA, Cadena SM, Gilbert JA, Meyer A, Nelson $\mathrm{HN}$, Swalley SE, et al. GDF11 increases with age and inhibits skeletal muscle regeneration. Cell Metab 2015;22: 164-74.

71. Egerman MA, Glass DJ. The role of GDF11 in aging and skeletal muscle, cardiac and bone homeostasis. Crit Rev Biochem Mol Biol 2019;54:174-83.

72. Zimmers TA, Jiang Y, Wang M, Liang TW, Rupert JE, Au ED, et al. Exogenous GDF11 induces cardiac and skeletal muscle dysfunction and wasting. Basic Res Cardiol 2017; 112:48.

73. Zhou Y, Sharma N, Dukes D, Myzithras MB, Gupta P, Khalil A, et al. GDF11 treatment attenuates the recovery of skeletal muscle function after injury in older rats. AAPS J 2017;19:431-7.

74. Jin Q, Qiao C, Li J, Xiao B, Li J, Xiao X. A GDF11/myostatin inhibitor, GDF11 propeptide-Fc, increases skeletal muscle mass and improves muscle strength in dystrophic mdx mice. Skelet Muscle 2019;9:16.

75. Mullican SE, Lin-Schmidt X, Chin CN, Chavez JA, Furman JL, Armstrong AA, et al. GFRAL is the receptor for GDF15 and the ligand promotes weight loss in mice and nonhuman primates. Nat Med 2017;23:1150-7.

76. Yang L, Chang CC, Sun Z, Madsen D, Zhu H, Padkjaer $\mathrm{SB}$, et al. GFRAL is the receptor for GDF15 and is required for the anti-obesity effects of the ligand. Nat Med 2017;23: 1158-66.

77. Ryu MJ, Kim SJ, Kim YK, Choi MJ, Tadi S, Lee MH, et al. Crifl deficiency reduces adipose OXPHOS capacity and triggers inflammation and insulin resistance in mice. PLoS Genet 2013;9:e1003356.

78. Chung HK, Ryu D, Kim KS, Chang JY, Kim YK, Yi HS, et al. Growth differentiation factor 15 is a myomitokine governing systemic energy homeostasis. J Cell Biol 2017;216: 149-65.

79. Moon JS, Goeminne LJE, Kim JT, Tian JW, Kim SH, Nga HT, et al. Growth differentiation factor 15 protects against the aging-mediated systemic inflammatory response in humans and mice. Aging Cell 2020;19:e13195.

80. Emmerson PJ, Wang F, Du Y, Liu Q, Pickard RT, Gonciarz $\mathrm{MD}$, et al. The metabolic effects of GDF15 are mediated by the orphan receptor GFRAL. Nat Med 2017;23:1215-9.

81. Hsu JY, Crawley S, Chen M, Ayupova DA, Lindhout DA, Higbee J, et al. Non-homeostatic body weight regulation through a brainstem-restricted receptor for GDF15. Nature 2017;550:255-9. 
82. Lerner L, Tao J, Liu Q, Nicoletti R, Feng B, Krieger B, et al. MAP3K11/GDF15 axis is a critical driver of cancer cachexia. J Cachexia Sarcopenia Muscle 2016;7:467-82.

83. Jones JE, Cadena SM, Gong C, Wang X, Chen Z, Wang SX, et al. Supraphysiologic administration of GDF11 induces cachexia in part by upregulating GDF15. Cell Rep 2018;22:1522-30.

84. Suriben R, Chen M, Higbee J, Oeffinger J, Ventura R, Li B, et al. Antibody-mediated inhibition of GDF15-GFRAL activity reverses cancer cachexia in mice. Nat Med 2020;26: 1264-70.

85. Arumugam M, Raes J, Pelletier E, Le Paslier D, Yamada T, Mende DR, et al. Enterotypes of the human gut microbiome. Nature 2011;473:174-80.

86. Yatsunenko T, Rey FE, Manary MJ, Trehan I, DominguezBello MG, Contreras M, et al. Human gut microbiome viewed across age and geography. Nature 2012;486:222-7.

87. Ticinesi A, Nouvenne A, Cerundolo N, Catania P, Prati B, Tana $\mathrm{C}$, et al. Gut microbiota, muscle mass and function in aging: a focus on physical frailty and sarcopenia. Nutrients 2019;11:1633.

88. Nay K, Jollet M, Goustard B, Baati N, Vernus B, Pontones $\mathrm{M}$, et al. Gut bacteria are critical for optimal muscle function: a potential link with glucose homeostasis. Am J Physiol Endocrinol Metab 2019;317:E158-71.

89. Claesson MJ, Jeffery IB, Conde S, Power SE, O’Connor EM, Cusack S, et al. Gut microbiota composition correlates with diet and health in the elderly. Nature 2012;488:178-84.

90. Vaiserman AM, Koliada AK, Marotta F. Gut microbiota: a player in aging and a target for anti-aging intervention. Ageing Res Rev 2017;35:36-45.

91. Koh A, Molinaro A, Stahlman M, Khan MT, Schmidt C, Manneras-Holm L, et al. Microbially produced imidazole propionate impairs insulin signaling through mTORC1. Cell 2018;175:947-61.

92. Enoki Y, Watanabe H, Arake R, Sugimoto R, Imafuku T, Tominaga $\mathrm{Y}$, et al. Indoxyl sulfate potentiates skeletal muscle atrophy by inducing the oxidative stress-mediated expression of myostatin and atrogin-1. Sci Rep 2016;6:32084.

93. Lahiri S, Kim H, Garcia-Perez I, Reza MM, Martin KA, Kundu $\mathrm{P}$, et al. The gut microbiota influences skeletal muscle mass and function in mice. Sci Transl Med 2019;11: eaan5662.

94. Manickam R, Oh HYP, Tan CK, Paramalingam E, Wahli W. Metronidazole causes skeletal muscle atrophy and modulates muscle chronometabolism. Int J Mol Sci 2018;19:
2418.

95. Blacher E, Bashiardes S, Shapiro H, Rothschild D, Mor U, Dori-Bachash $\mathrm{M}$, et al. Potential roles of gut microbiome and metabolites in modulating ALS in mice. Nature 2019; 572:474-80.

96. Grosicki GJ, Fielding RA, Lustgarten MS. Gut microbiota contribute to age-related changes in skeletal muscle size, composition, and function: biological basis for a gut-muscle axis. Calcif Tissue Int 2018;102:433-42.

97. Symons TB, Sheffield-Moore M, Wolfe RR, Paddon-Jones D. A moderate serving of high-quality protein maximally stimulates skeletal muscle protein synthesis in young and elderly subjects. J Am Diet Assoc 2009;109:1582-6.

98. Kim IY, Schutzler S, Schrader A, Spencer H, Kortebein P, Deutz NE, et al. Quantity of dietary protein intake, but not pattern of intake, affects net protein balance primarily through differences in protein synthesis in older adults. Am J Physiol Endocrinol Metab 2015;308:E21-8.

99. Bauer J, Biolo G, Cederholm T, Cesari M, Cruz-Jentoft AJ, Morley JE, et al. Evidence-based recommendations for optimal dietary protein intake in older people: a position paper from the PROT-AGE Study Group. J Am Med Dir Assoc 2013;14:542-59.

100. McGlory C, van Vliet S, Stokes T, Mittendorfer B, Phillips SM. The impact of exercise and nutrition on the regulation of skeletal muscle mass. J Physiol 2019;597:1251-8.

101. Dillon EL, Sheffield-Moore M, Paddon-Jones D, Gilkison C, Sanford AP, Casperson SL, et al. Amino acid supplementation increases lean body mass, basal muscle protein synthesis, and insulin-like growth factor-I expression in older women. J Clin Endocrinol Metab 2009;94:1630-7.

102. Cruz-Jentoft AJ, Landi F, Schneider SM, Zuniga C, Arai H, Boirie Y, et al. Prevalence of and interventions for sarcopenia in ageing adults: a systematic review. Report of the International Sarcopenia Initiative (EWGSOP and IWGS). Age Ageing 2014;43:748-59.

103. Cortassa S, Caceres V, Bell LN, O’Rourke B, Paolocci N, Aon MA. From metabolomics to fluxomics: a computational procedure to translate metabolite profiles into metabolic fluxes. Biophys J 2015;108:163-72.

104. Narkar VA, Downes M, Yu RT, Embler E, Wang YX, Banayo E, et al. AMPK and PPARdelta agonists are exercise mimetics. Cell 2008;134:405-15.

105. Kim JA, Roy RR, Zhong H, Alaynick WA, Embler E, Jang $\mathrm{C}$, et al. $\operatorname{PPAR} \delta$ preserves a high resistance to fatigue in the mouse medial gastrocnemius after spinal cord transection. 
Muscle Nerve 2016;53:287-96.

106. Mosti MP, Stunes AK, Ericsson M, Pullisaar H, Reseland JE, Shabestari M, et al. Effects of the peroxisome proliferator-activated receptor (PPAR)- $\delta$ agonist GW501516 on bone and muscle in ovariectomized rats. Endocrinology 2014;155:2178-89.

107. Sahebkar A, Chew GT, Watts GF. New peroxisome proliferator-activated receptor agonists: potential treatments for atherogenic dyslipidemia and non-alcoholic fatty liver disease. Expert Opin Pharmacother 2014;15:493-503.

108. Kadayat TM, Shrestha A, Jeon YH, An H, Kim J, Cho SJ, et al. Targeting peroxisome proliferator-activated receptor delta (PPAR 8$)$ : a medicinal chemistry perspective. J Med Chem 2020;63:10109-34.

109. Winder WW, Hardie DG. Inactivation of acetyl-CoA carboxylase and activation of AMP-activated protein kinase in muscle during exercise. Am J Physiol 1996;270(2 Pt 1):E299-304.

110. Wojtaszewski JF, Nielsen P, Hansen BF, Richter EA, Kiens B. Isoform-specific and exercise intensity-dependent activation of 5'-AMP-activated protein kinase in human skeletal muscle. J Physiol 2000;528(Pt 1):221-6.

111. Hardie DG, Schaffer BE, Brunet A. AMPK: an energysensing pathway with multiple inputs and outputs. Trends Cell Biol 2016;26:190-201.

112. Steinberg GR, O’Neill HM, Dzamko NL, Galic S, Naim T, Koopman R, et al. Whole body deletion of AMP-activated protein kinase beta 2 reduces muscle AMPK activity and exercise capacity. J Biol Chem 2010;285:37198-209.

113. Thomas MM, Wang DC, D'Souza DM, Krause MP, Layne AS, Criswell DS, et al. Muscle-specific AMPK $\beta 1 \beta 2$-null mice display a myopathy due to loss of capillary density in nonpostural muscles. FASEB J 2014;28:2098-107.

114. Bujak AL, Crane JD, Lally JS, Ford RJ, Kang SJ, Rebalka IA, et al. AMPK activation of muscle autophagy prevents fasting-induced hypoglycemia and myopathy during aging. Cell Metab 2015;21:883-90.

115. Lantier L, Mounier R, Leclerc J, Pende M, Foretz M, Viollet B. Coordinated maintenance of muscle cell size control by AMP-activated protein kinase. FASEB J 2010;24:3555-61.

116. Mu J, Barton ER, Birnbaum MJ. Selective suppression of AMP-activated protein kinase in skeletal muscle: update on 'lazy mice'. Biochem Soc Trans 2003;31(Pt 1):236-41.

117. Thomson DM. The role of AMPK in the regulation of skeletal muscle size, hypertrophy, and regeneration. Int J Mol Sci 2018;19:3125.
118. Winder WW, Holmes BF, Rubink DS, Jensen EB, Chen M, Holloszy JO. Activation of AMP-activated protein kinase increases mitochondrial enzymes in skeletal muscle. J Appl Physiol (1985) 2000;88:2219-26.

119. Pauly M, Chabi B, Favier FB, Vanterpool F, Matecki S, Fouret $\mathrm{G}$, et al. Combined strategies for maintaining skeletal muscle mass and function in aging: myostatin inactivation and AICAR-associated oxidative metabolism induction. J Gerontol A Biol Sci Med Sci 2015;70:1077-87.

120. Ljubicic V, Miura P, Burt M, Boudreault L, Khogali S, Lunde JA, et al. Chronic AMPK activation evokes the slow, oxidative myogenic program and triggers beneficial adaptations in mdx mouse skeletal muscle. Hum Mol Genet 2011; 20:3478-93.

121. Pauly M, Daussin F, Burelle Y, Li T, Godin R, Fauconnier J, et al. AMPK activation stimulates autophagy and ameliorates muscular dystrophy in the mdx mouse diaphragm. Am J Pathol 2012;181:583-92.

122. Hall DT, Griss T, Ma JF, Sanchez BJ, Sadek J, Tremblay AMK, et al. The AMPK agonist 5-aminoimidazole-4-carboxamide ribonucleotide (AICAR), but not metformin, prevents inflammation-associated cachectic muscle wasting. EMBO Mol Med 2018;10:e8307.

123. Myers RW, Guan HP, Ehrhart J, Petrov A, Prahalada S, Tozzo E, et al. Systemic pan-AMPK activator MK-8722 improves glucose homeostasis but induces cardiac hypertrophy. Science 2017;357:507-11.

124. Esquejo RM, Salatto CT, Delmore J, Albuquerque B, Reyes A, Shi Y, et al. Activation of liver AMPK with PF-06409577 corrects NAFLD and lowers cholesterol in rodent and primate preclinical models. EBioMedicine 2018;31:122-32.

125. Menzies KJ, Singh K, Saleem A, Hood DA. Sirtuin 1-mediated effects of exercise and resveratrol on mitochondrial biogenesis. J Biol Chem 2013;288:6968-79.

126. Lagouge M, Argmann C, Gerhart-Hines Z, Meziane H, Lerin C, Daussin F, et al. Resveratrol improves mitochondrial function and protects against metabolic disease by activating SIRT1 and PGC-1alpha. Cell 2006;127:1109-22.

127. Timmers S, Konings E, Bilet L, Houtkooper RH, van de Weijer T, Goossens GH, et al. Calorie restriction-like effects of 30 days of resveratrol supplementation on energy metabolism and metabolic profile in obese humans. Cell Metab 2011;14:612-22.

128. Dufour CR, Wilson BJ, Huss JM, Kelly DP, Alaynick WA, Downes M, et al. Genome-wide orchestration of cardiac functions by the orphan nuclear receptors ERRalpha and 
gamma. Cell Metab 2007;5:345-56.

129. Rangwala SM, Wang X, Calvo JA, Lindsley L, Zhang Y, Deyneko G, et al. Estrogen-related receptor gamma is a key regulator of muscle mitochondrial activity and oxidative capacity. J Biol Chem 2010;285:22619-29.

130. Lee SJ, McPherron AC. Regulation of myostatin activity and muscle growth. Proc Natl Acad Sci U S A 2001;98:9306-11.

131. Amato AA, Sivakumar K, Goyal N, David WS, Salajegheh M, Praestgaard J, et al. Treatment of sporadic inclusion body myositis with bimagrumab. Neurology 2014;83:223946.

132. Tillner J, Posch MG, Wagner F, Teichert L, Hijazi Y, Einig $\mathrm{C}$, et al. A novel dual glucagon-like peptide and glucagon receptor agonist SAR425899: Results of randomized, placebo-controlled first-in-human and first-in-patient trials. Diabetes Obes Metab 2019;21:120-8.

133. Tai J, Liu W, Li Y, Li L, Holscher C. Neuroprotective effects of a triple GLP-1/GIP/glucagon receptor agonist in the APP/PS1 transgenic mouse model of Alzheimer's disease. Brain Res 2018;1678:64-74.

134. Dollerup OL, Chubanava S, Agerholm M, Sondergard SD, Altıntas A, Moller AB, et al. Nicotinamide riboside does not alter mitochondrial respiration, content or morphology in skeletal muscle from obese and insulin-resistant men. J Physiol 2020;598:731-54.
135. Mills KF, Yoshida S, Stein LR, Grozio A, Kubota S, Sasaki $\mathrm{Y}$, et al. Long-term administration of nicotinamide mononucleotide mitigates age-associated physiological decline in mice. Cell Metab 2016;24:795-806.

136. Guo S, Chen Q, Sun Y, Chen J. Nicotinamide protects against skeletal muscle atrophy in streptozotocin-induced diabetic mice. Arch Physiol Biochem 2019;125:470-7.

137. Wilkinson DJ, Brook MS, Smith K, Atherton PJ. Stable isotope tracers and exercise physiology: past, present and future. J Physiol 2017;595:2873-82.

138. Hellerstein MK. New stable isotope-mass spectrometric techniques for measuring fluxes through intact metabolic pathways in mammalian systems: introduction of moving pictures into functional genomics and biochemical phenotyping. Metab Eng 2004;6:85-100.

139. Hinkley JM, Cornnell HH, Standley RA, Chen EY, Narain NR, Greenwood BP, et al. Older adults with sarcopenia have distinct skeletal muscle phosphodiester, phosphocreatine, and phospholipid profiles. Aging Cell 2020;19: e13135.

140. Makimura H, Stanley TL, Sun N, Hrovat MI, Systrom DM, Grinspoon SK. The association of growth hormone parameters with skeletal muscle phosphocreatine recovery in adult men. J Clin Endocrinol Metab 2011;96:817-23. 